\begin{abstract}
Iranica
Abstracta Iranica Revue bibliographique pour le domaine irano-aryen

Volume 37-38-39 | 2018

Comptes rendus des publications de 2014-2016
\end{abstract}

\title{
Jean Kellens. Cinq Cours Sur Les Yašts de L'Avesta
}

\section{Götz König}

\section{(2) OpenEdition}

\section{Journals}

\section{Édition électronique}

URL : http://journals.openedition.org/abstractairanica/43749

DOI : 10.4000/abstractairanica.43749

ISBN : 1961-960X

ISSN : 1961-960X

Éditeur :

CNRS (UMR 7528 Mondes iraniens et indiens), Éditions de l'IFRI

Référence électronique

Götz König, "Jean Kellens. Cinq Cours Sur Les Yašts de L'Avesta », Abstracta Iranica [En ligne], Volume 37-38-39 | 2018, document 13, mis en ligne le 30 décembre 2018, consulté le 28 septembre 2020. URL : http://journals.openedition.org/abstractairanica/43749; DOI : https://doi.org/10.4000/ abstractairanica.43749

Ce document a été généré automatiquement le 28 septembre 2020

Tous droits réservés 


\title{
Jean Kellens. Cinq Cours Sur Les Yašts de L'Avesta
}

\author{
Götz König
}

\section{RÉFÉRENCE}

Jean Kellens. Cinq Cours Sur Les Yašts de L'Avesta. Paris : Association pour l'Avancement des études iraniennes, 2016, 192 p. (Cahiers de Studia Iranica 59)

1 This book is a collection and republication of a total of eight papers by Jean Kellens dedicated to the Avestan Yašts. Apart from the introductory text from 1978, they originate from two series of lectures presented at the Collège de France in 1997-2000 and 2008-2011 and offer a panorama of Kellens' contemplation of these texts.

2 The topic is treated in a selective manner; it discusses the 'Great Yašts', viz. Yt 10 (and Yt 8), Yt 19, Yt 5 (and the so-called catalogues of worshippers) and Yt 13 as focus of the individual articles. This roughly corresponds to the hymns that Kellens regards as those once intercalated in the Yasna (p. 174). The Yašts of the Xorde Avesta as well as the Xorde Avesta itself are not considered.

3 All texts share the by and large strictly immanent method of analysis within which Kellens combines primarily a structural inquiry into the texts with micro-analyses of grammar, partly also with a deconstruction of results provided by previous research. When seen in context, the Yašts in question reveal themselves as reflecting on time. In the mythic image as well as in their dialectic relatedness to ritual structures, they all revolve around the themes of immortality and pre-existence along with a world history composed of different phases. Particularly in the latest texts, Kellens breaks with a perspective that merely saw the Yašts as a spiritual-religious recurrence of a pre-Gathic world. Instead, the Yašts are (as is the Young Avesta in general for Kellens) witnesses of a theology which reorients the inherited tradition along the lines of these key concepts. 


\section{AUTEURS}

GÖTZ KÖNIG

Université libre de Berlin 